\title{
Growth Hormone after Oral Glucose Overload: Revision of Reference Values in Normal Subjects
}

\begin{abstract}
The evaluation of growth hormone (GH) secretion continues to be important in acromegaly and the nadir $\mathrm{GH}$ (n-GH) level in the oral glucose tolerance test (OGTT) is the gold standard for the demonstration of secretory autonomy of this hormone. $\mathrm{n}-\mathrm{GH}$ levels $<1 \mu \mathrm{g} / \mathrm{L}$ are defined as normal suppression but, using current assays, $\mathrm{n}-\mathrm{GH}<1 \mu \mathrm{g} / \mathrm{L}$ is detected in patients with untreated acromegaly and this value seems to be much lower in normal subjects. The objective of the present study was to evaluate $n-G H$ levels in the OGTT in normal subjects using three different assays (GH ICMA Immulite; GH IRMA DSL and GH IFMA AutoDelfia). Two-hundred apparently healthy subjects ( 120 women) ranging in age from 18 to 70 years and with a $\mathrm{BMI} \geq 18.5$ and $\leq 27 \mathrm{~kg} / \mathrm{m}^{2}$, who used no medications and presented normal glycemia, blood count, albumin, creatinine, TSH, SGOT, SGPT and bilirubin were studied. Serum samples were obtained before and $30,60,90$ and $120 \mathrm{~min}$ after oral administration of $75 \mathrm{~g}$ glucose. The test was repeated after 4 weeks in 157 participants, with the same protocol being used in 79 and 78 receiving an overload of $100 \mathrm{~g}$ glucose. $\mathrm{n}$-GH cut-off values (97.5th percentile) were higher in women than in men (GH-IFMA: 0.30 versus $0.11 \mu \mathrm{g} / \mathrm{L}$; GH-ICMA: 0.60 versus $0.25 \mu \mathrm{g} / \mathrm{L}$; GH-IRMA: 0.20 versus $0.10 \mu \mathrm{g} / \mathrm{L}$, respectively). No correlation was observed between $\mathrm{n}-\mathrm{GH}$ and age or BMI. A difference was only observed when comparing women $\leq 35$ years $(n=40)$ versus $>35$ years $(n=80)$, with higher values in the former ( $n-G H$ cut-off in this subgroup: GH-IFMA 0.40 versus $0.26 \mu \mathrm{g} / \mathrm{L}, \mathrm{GH}-\mathrm{ICMA} 0.74$ versus $0.50 \mu \mathrm{g} / \mathrm{L}$, GH-IRMA 0.25 versus $0.15 \mu \mathrm{g} / \mathrm{L})$. A good correlation was observed between the assays ( $r$ $=0.9-0.96)$, however, the highest values were always obtained with the Immulite assay. Test repetition with $75 \mathrm{~g}$ oral glucose showed a variation in $\mathrm{n}-\mathrm{GH}<10.2 \%$ (GH-IFMA),$<13.4 \%$ (GH-ICMA) and $<11 \%$ (GH-IRMA) in $95 \%$ of the subjects. This variation was similar when the test was repeated with $100 \mathrm{~g}$ glucose. A good correlation was observed between $n-G H$ in the first and second test $(r=0.83-0.92)$. We suggest the following $\mathrm{n}-\mathrm{GH}$ reference values: for men, $0.14 \mu \mathrm{g} / \mathrm{L}$ for the GH IRMA DSL and GH IFMA AutoDelfia kits and $0.25 \mu \mathrm{g} / \mathrm{L}$ for the GH ICMA Immulite kit; for women, $0.25 \mu \mathrm{g} / \mathrm{L}, 0.40 \mu \mathrm{g} / \mathrm{L}$ and $0.70 \mu \mathrm{g} / \mathrm{L}$, respectively. (Arq Bras Endocrinol Metab 2008; 52/7:1139-1144)
\end{abstract}

Keywords: Acromegaly; Oral glucose tolerance test; Growth hormone; Reference values

\section{RESUMO}

Hormônio de Crescimento Depois da Intolerância à Glicose: Revisão dos Valores Normais de Testes.

A avaliação da secreção do hormônio de crescimento (GH) permanece importante na acromegalia e o nadir do $\mathrm{GH}(\mathrm{n}-\mathrm{GH})$ no teste de tolerância oral à glicose (TTOG) é o padrão-ouro na demonstração da autonomia secretória deste hormônio. Considera-se supressão normal valores $<1 \mu \mathrm{g} / \mathrm{L}$, mas, com os ensaios atuais, $\mathrm{n}-\mathrm{GH}<$ $1 \mu \mathrm{g} / \mathrm{L}$ é encontrado em pacientes com acromegalia não-tratada; e em indivíduos normais este valor parece ser bem menor. O objetivo do estudo foi avaliar o n-GH no TTOG em indivíduos normais, usando três ensaios diferentes (GH ICMA Immulite, GH IRMA DSL e GH IFMA AutoDelfia). Duzentos voluntários aparentemente saudáveis (120 mulheres) com idade entre 18 e 70 anos e índice de massa corporal original

\author{
Pedro W. S. Rosário \\ MARIANA S. FuRTADO
}

Serviço de Endocrinologia da Santa Casa de Belo Horizonte e Setor de Hormônios do Laboratório ANALYS (PWSR), Belo Horizonte, MG, Brasil; Faculdade de Medicina do Vale do Aço (MSF), Ipatinga, MG, Brasil.
Recebido em 12/5/2008 Aceito em 12/8/2008 
(IMC) $\geq 18,5$ e $\leq 27 \mathrm{~kg} / \mathrm{m}^{2}$, que não usavam medicamentos e apresentavam hemograma, glicemia e dosagens séricas de albumina, creatinina, TSH, TGO, TGP e bilirrubinas normais, foram estudados. Amostras de soro foram obtidas antes e 30, 60, 90 e 120 minutos após administração oral de $75 \mathrm{~g}$ de glicose. 0 teste foi repetido após quatro semanas em 157 participantes, com o mesmo protocolo sendo usado em 79 pacientes e sobrecarga oral de $100 \mathrm{~g}$ de glicose nos outros 78 . Os valores de corte do $\mathrm{n}-\mathrm{GH}$ (percentil 97,5 ) foram maiores em mulheres que nos homens (GH-IFMA: 0,30 versus $0,11 \mu \mathrm{g} / \mathrm{L} ; \mathrm{GH}-\mathrm{ICMA}: 0,60$ versus $0,25 \mu \mathrm{g} / \mathrm{L} ; \mathrm{GH}-\mathrm{IRMA}$ : 0,20 versus $0,10 \mu \mathrm{g} / \mathrm{L}$, respectivamente). Nenhuma correlação foi observada entre $\mathrm{n}$-GH e idade ou IMC. Uma diferença foi vista apenas quando foi comparado muIheres $\leq 35$ anos $(n=40)$ versus $>35$ anos $(n=80)$, com valores maiores nas primeiras (valor de corte do $\mathrm{n}-\mathrm{GH}$ neste subgrupo: $\mathrm{GH}$-IFMA 0,40 versus $0,26 \mu \mathrm{g} / \mathrm{L}$, $\mathrm{GH}-\mathrm{ICMA} 0,74$ versus $0,50 \mu \mathrm{g} / \mathrm{L}$, GH-IRMA 0,25 versus $0,15 \mu \mathrm{g} / \mathrm{L}$ ). Houve boa correlação entre os ensaios $(r=0,9-0,96)$, mas valores maiores foram sempre obtidos com o kit Immulite. A repetição do teste com $75 \mathrm{~g}$ de glicose oral mostrou variação no $\mathrm{n}-\mathrm{GH}<10,2 \%$ (GH-IFMA), < 13,4\% (GH-ICMA) e < 11\% (GH-IRMA) em 95\% dos indivíduos. Esta variação foi similar quando o teste foi repetido com $100 \mathrm{~g}$ de glicose. Uma boa correlação foi observada entre o $\mathrm{n}-\mathrm{GH}$ no primeiro e segundo testes $(r=0,83-0,92)$. Sugere-se os seguintes valores de referência para o $n-G H$ : para homens, 0,14 $\mathrm{gg} / \mathrm{L}$ para os kits GH IRMA DSL e GH IFMA Auto Delfia e 0,25 $\mu \mathrm{g} / \mathrm{L}$ para o kit GH ICMA Immulite; para mulheres, 0,25 $\mu \mathrm{g} / \mathrm{L}, 0,40 \mu \mathrm{g} / \mathrm{L}$ e 0,70 $\mu \mathrm{g} / \mathrm{L}$, respectivamente. (Arq Bras Endocrinol Metab 2008; 52/7:1139-1144)

Descritores: Acromegalia; Teste de tolerância oral à glicose; Hormônio de crescimento; Valores de referência

\section{INTRODUCTION}

$\mathrm{T}$ he evaluation of growth hormone $(\mathrm{GH})$ secretion is still important for the acromegaly management. For the diagnosis of the disease, elevated IGF-1, although highly specific, does not circumvent the GH suppression test after an oral glucose overload (1-3). In addition, elevated and non-suppressed levels of $\mathrm{GH}$ permit the diagnosis of acromegaly in the rare cases with normal IGF-1. Treatment is not only aimed at normalization of IGF- 1 but also at the control of GH secretion $(1,3)$, considering that a more consistent correlation with mortality is observed for GH levels rather than IGF-1 $(3,4)$. Finally, technical problems with the assays and the need for specific population reference values limit the use of IGF-1 as a single biochemical parameter to define patients' management with acromegaly without considering concomitant GH levels.

The nadir GH (n-GH) level in the oral glucose tolerance test (OGTT) is the gold standard for the demonstration of its secretory autonomy, a characteristic of untreated or active acromegaly (3). At present, values $<1 \mu \mathrm{g} / \mathrm{L}$ are considered to indicate normal suppression, although data validating this cut-off have not been presented in the Cortina Consensus (2). A change in this parameter has been proposed (2) in view of the fact that, using news assays, an $\mathrm{n}-\mathrm{GH}<\mathrm{l} \mu \mathrm{g} / \mathrm{L}$, i.e., suppressed according to the current criterion (1), can be found in patients with untreated acromegaly $(5,6)$, whereas in normal individuals this value does not exceed $0.30 \mu \mathrm{g} / \mathrm{L}(2)$.

Many studies evaluating n-GH present flaws may compromise the suggested cut-off values. In this respect, preanalytical factors include relatively small samples, especially comparing the subgroups (such as gender and age); and poorly detailed information about the exclusion of potential interfering factors, whether these factors were only identified by clinical examination or by minimal laboratory investigation. In addition, the protocol used is not always the currently recommended (measurement of $\mathrm{GH}$ at baseline and $30,60,90$ and $120 \mathrm{~min}$ after $75 \mathrm{~g}$ of oral glucose) $(1,3)$, with some studies using $100 \mathrm{~g}$ glucose (5-8) and occasionally omitting the collection at $30(7,9), 90(10)$ or $120 \mathrm{~min}(8)$, with the possibility that these modifications may affect the results. As an analytical factor, the use of standards which were not calibrated with highly 
purified preparations of $22-\mathrm{kDa} \mathrm{GH}$ as currently recommended has been observed (5,9-14). In addition, little is known about the reproducibility of n-GH.

In view of the above considerations and the need for a specific cut-off for each assay, the objective of the present study was to evaluate n-GH levels in the OGTT in normal subjects using three assays used in Brazil.

\section{METHODS}

\section{Subjects}

Two hundred ninety-two subjects apparently healthy (absence of diabetes, kidney or liver disease and thyroid dysfunction), eutrophic, and not using any medications (including anovulatory agents, estrogens or corticosteroids) were initially evaluated. Pregnant women were excluded. In the case of women before menopause, only those with regular menstrual cycles were evaluated. All subjects were submitted to laboratory investigation and only those with fasting glycemia $<100 \mathrm{mg} /$ $\mathrm{dL}$ and $2 \mathrm{~h}$ post-dextrose $<140 \mathrm{mg} / \mathrm{dL}$, normal blood count and normal serum levels of albumin, creatinine, TSH, SGOT, SGPT and bilirubin were selected for the study. This group consisted of two-hundred volunteers ( 120 women and 80 men) ranging in age from 18 to 70 years (median of 44 years) with a body mass index $(\mathrm{BMI}) \geq 18.5$ and $\leq 27 \mathrm{~kg} / \mathrm{m}^{2}$ (median of $24.2 \mathrm{~kg} / \mathrm{m}^{2}$ for men and $23.3 \mathrm{~kg} / \mathrm{m}^{2}$ for women).

The study and its respective protocol were approved by the Ethics Committee of our institution and informed consent was obtained from all subjects.

\section{Study protocol}

Serum samples were obtained before and 30, 60, 90 and $120 \mathrm{~min}$ after oral administration of $75 \mathrm{~g}$ glucose $(1,3)$. The samples were collected in the morning after an approximately 10 -h fast, with the subject resting for $20 \mathrm{~min}$ before and during the test. Premenopausal women were evaluated during the follicular phase of the menstrual cycle (3rd to 8th day). The serum samples were stored frozen at $-80^{\circ} \mathrm{C}$ in multiple aliquots until the time for analysis. In $\mathrm{n}-\mathrm{GH}$ reproducibility evaluation, 157 participants agreed to repeat the test after 4 weeks. The same protocol was used in 79 of these subjects, whereas in 78 the oral glucose overload was changed to $100 \mathrm{~g}$.

\section{Assays}

In order to have the results taken in Brazil accepted, assays at the main Brazilian neuroendocrinology cen- ters were used (GH IFMA AutoDelfia, Wallac OY, Turku, Finland; GH ICMA Immulite, Diagnostic Products Corporation, Los Angeles, CA and GH IRMA, Diagnostic Systems Laboratories, Inc., Webster, TX). The values obtained with the three assays at our laboratory for 20 replicates of human serum containing 0 $\mu \mathrm{g} / \mathrm{L} \mathrm{GH}$ (standard 0 of the IRMA DSL kit) were $\leq$ $0.05 \mu \mathrm{g} / \mathrm{L}$ (analytical sensitivity). The standards provided by the kits were calibrated to the WHO (World Health Organization) 2nd International Standard (IS) 98/574 (Immulite), 1st IS 88/624 (IRMA DSL) and lst International Reference Preparation (IRP) 80/505 (AutoDelfia). The results are expressed as $\mu \mathrm{g} / \mathrm{L}$ (14). The authors state that the choice of the commercial kits was solely based on the fact that they are used in Brazil and that there was no conflict of interests.

\section{Statistical analysis}

The cut-off was defined as the $97.5^{\text {th }}$ percentile of the values found. Statistical analysis was performed using the SPSS, version 14, and MedCalc, version 9, programs. The Spearman correlation test was used to analyze the correlation between GH levels in the three assays, between n-GH in the first and second test, and between n-GH and age, BMI, peak glycemia and glycemic elevation during the OGTT. The nonparametric Kruskal-Wallis test and the parametric Shapiro-Wilk test were used to compare GH values obtained in the different assays or between groups. P values $<0.05$ were considered to be statistically significant.

\section{RESULTS}

The correlation between assays was good $(\mathrm{r}=0.9-0.96$, $\mathrm{p}<0.001)$. However, the highest values were always obtained with the Immulite kit (Figure 1). In 20 samples with a GH concentration ranging from 0.10 to 0.5 $\mu \mathrm{g} / \mathrm{L}$ (mean of 0.28 for GH-IFMA, 0.30 for GH-IC$\mathrm{MA}$ and $0.26 \mu \mathrm{g} / \mathrm{L}$ for GH-IRMA), the highest intraassay variation was $7 \%, 9.4 \%$ and $7.8 \%$, respectively.

The $\mathrm{n}$-GH cut-off values were higher in women than in men (GH-IFMA: 0.30 versus $0.11 \mu \mathrm{g} / \mathrm{L} ; \mathrm{GH}-$ ICMA: 0.60 versus $0.25 \mu \mathrm{g} / \mathrm{L}$; GH-IRMA: 0.20 versus $0.10 \mu \mathrm{g} / \mathrm{L}$, respectively $(\mathrm{p}<0.01$ for all assays $)$, as were the maximum values found (GH-IFMA: 0.47 versus $0.14 \mu \mathrm{g} / \mathrm{L}$; GH-ICMA: 0.85 versus $0.30 \mu \mathrm{g} / \mathrm{L}$; GH-IRMA: 0.30 versus $0.12 \mu \mathrm{g} / \mathrm{L}$, respectively). No $\mathrm{n}$-GH values $\geq 1 \mu \mathrm{g} / \mathrm{L}$ were observed. None of the 

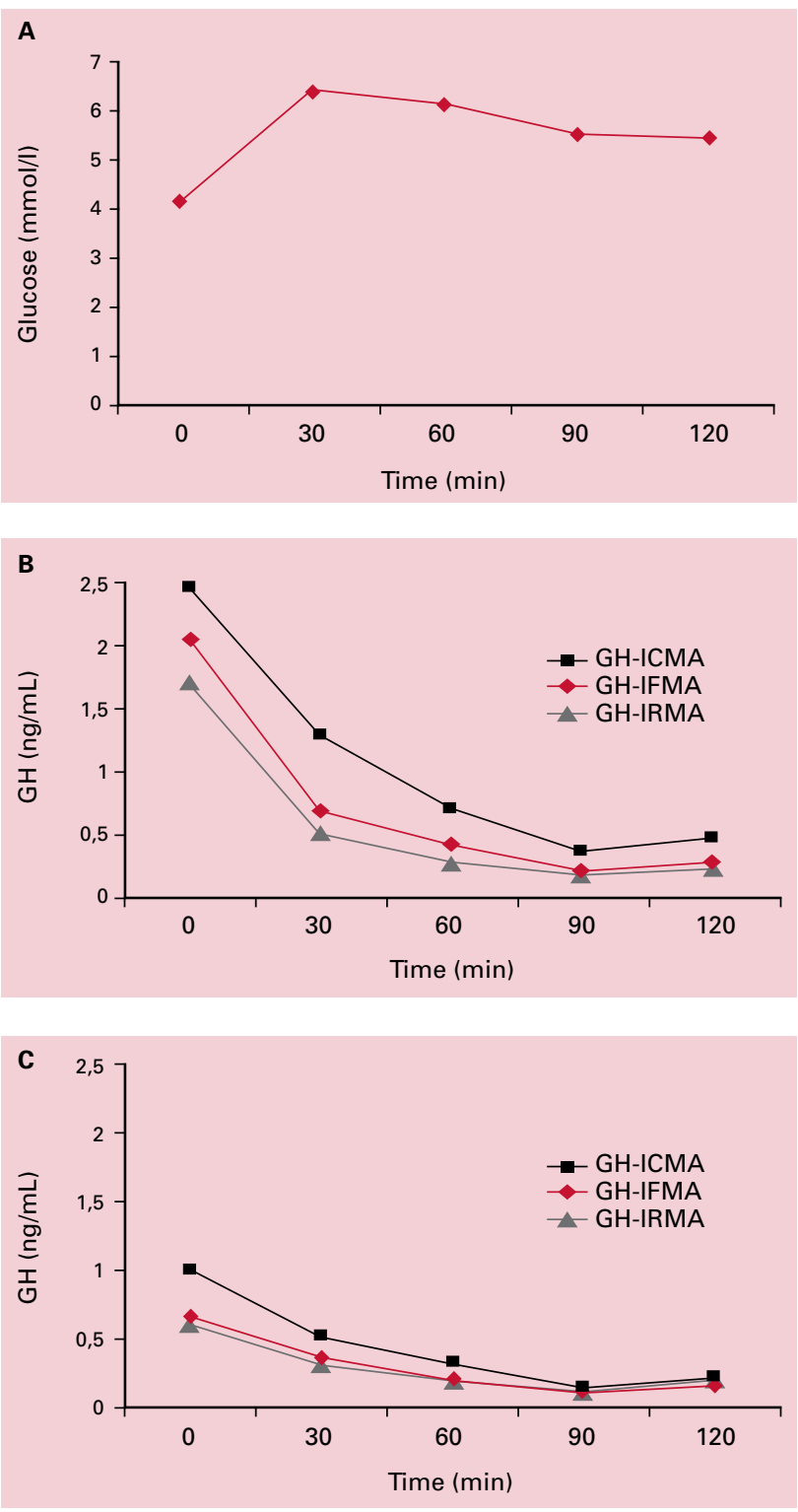

Figure 1. A. Mean glucose levels during an OGTT. B. Mean GH levels during an OGTT in women. C. Mean GH levels during an OGTT in men.

assays detected a correlation between n-GH levels and age or BMI. A difference was only observed when comparing women $\leq 35$ years $(n=40)$ versus $>35$ years $(\mathrm{n}=80)$, with higher values in the former ( $\mathrm{n}-\mathrm{GH}$ cut off in this subgroup: GH-IFMA $0.4 \mu \mathrm{g} / \mathrm{L}$ versus 0.26 $\mu \mathrm{g} / \mathrm{L}, \mathrm{GH}-\mathrm{ICMA} 0.74 \mu \mathrm{g} / \mathrm{L}$ versus $0.50 \mu \mathrm{g} / \mathrm{L}$ and GH-IRMA $0.25 \mu \mathrm{g} / \mathrm{L}$ versus $0.15 \mu \mathrm{g} / \mathrm{L}$ ( $\mathrm{p}<0.05$ for all assays). The maximum value detected by each assay was also observed in this subgroup (young women).
The time of the test necessary to reach n-GH in each assay is shown in Table 1 and mean GH levels during an OGTT in Figure 1.

Table 1. Percentage distribution of patients according to the amount of time necessary to reach $n-G H$.

\begin{tabular}{lccccc}
\hline Assay & $\begin{array}{c}\text { Undetectable } \\
\text { basal GH }\end{array}$ & $\mathbf{3 0} \mathbf{m i n}$ & $\mathbf{6 0} \mathbf{m i n}$ & $\mathbf{9 0} \mathbf{m i n}$ & $\begin{array}{c}\mathbf{1 2 0} \\
\mathbf{m i n}\end{array}$ \\
$\begin{array}{l}\text { GH- } \\
\text { ICMA }\end{array}$ & $1 \%$ & $23 \%$ & $47 \%$ & $97 \%$ & $100 \%$ \\
GH-IFMA & $3 \%$ & $29 \%$ & $55 \%$ & $96 \%$ & $100 \%$ \\
GH- & $4 \%$ & $26 \%$ & $54 \%$ & $96 \%$ & $100 \%$ \\
IRMA & & & & & \\
\hline
\end{tabular}

The reproducibility of $\mathrm{n}-\mathrm{GH}$ in the OGTT was good. In the 79 subjects who performed the second test with $75 \mathrm{~g}$ glucose 4 weeks later, comparison of $\mathrm{n}$-GH between the first and second test showed a variation $<10.2 \%$ (GH-IFMA), $<13.4 \%$ (GH-ICMA) and $<$ $11 \%$ (GH-IRMA) in $95 \%$ of them. The correlation between $\mathrm{n}-\mathrm{GH}$ in the first and second test was $\operatorname{good}(\mathrm{r}=$ $0.86-0.91, \mathrm{p}<0.001)$. The variation was $<9.2 \%(\mathrm{GH}-$ IFMA),$<14 \%$ (GH-ICMA) and $<9.8 \%$ (GH-IRMA) em $95 \%$ of the 78 participants in which the test was repeated using $100 \mathrm{~g}$ glucose. In these cases, the correlation between $\mathrm{n}-\mathrm{GH}$ in the first and second test was also $\operatorname{good}(\mathrm{r}=0.83-0.92, \mathrm{p}<0.001)$. Also regarding the influence of glucose overload on GH suppression, we observed no correlation between n-GH and peak glycemia or the amplitude of glycemic elevation in the 357 tests analyzed for any of the assays.

\section{DISCUSSION}

The present study confirms that normal n-GH levels during the OGTT are lower than $1 \mu \mathrm{g} / \mathrm{L}$ when current assays are used (1). In addition, the study shows that cut-off values vary according to the assay used, in agreement with the findings of Markkanen et al. (11) and Arafat et al. (15), a fact that impairs the adoption of a universal cut-off value (2). The main reasons for the discrepancies between results are the heterogeneity of GH molecules, the use of monoclonal or polyclonal antibodies, the interference from $\mathrm{GH}$ binding protein and other matrix components, and the use of different standard preparations to calibrate GH assays.

Among the variables that may influence n-GH levels in healthy subjects, gender, age and BMI are the most studied. A difference between genders was obser- 
ved in the present study, with women showing higher $\mathrm{n}-\mathrm{GH}$ levels than men as reported in most studies (8,11-13,15-17). Although GH secretion decreases progressively with age (about $14 \%$ per decade) (2), we found no correlation between $\mathrm{n}-\mathrm{GH}$ and this variable, in agreement with other investigators $(7,8,11,12,16)$. What is observed is that young and young adult women present higher $\mathrm{n}-\mathrm{GH}$ levels and require a distinct cut-off, as previously reported by Costa et al. (13) and Gullu et al. (17). In the series of Arafat et al. (15) involving 213 subjects ( 147 women) which demonstrated an inverse correlation between age and $\mathrm{n}-\mathrm{GH}$, lower values were in fact observed from the fifth decade of life on. The influence of BMI, which was found to be negatively correlated in two important studies $(10,15)$, was not confirmed in the present study, similar to the findings of other series $(7,8,12,16,17)$. However, since we did not evaluate obese patients, it is possible that these patients in fact present even lower n-GH levels than those observed in the present study, especially in the case of a BMI $>35-40 \mathrm{~kg} / \mathrm{m}^{2}(15)$.

We compared our results to those reported in other studies using the same assays (Table 2). Freda et al. (7) reported a cut-off of $0.14 \mu \mathrm{g} / \mathrm{l}$ for men $(\mathrm{n}=26)$ using the GH IRMA DSL kit. When using the GH IFMA AutoDelfia kit, all men of our series $(n=80)$ and of two other studies $(11,12)(\mathrm{n}=50)$ presented $\mathrm{n}-\mathrm{GH}$ levels $\leq$ $0.14 \mu \mathrm{g} / \mathrm{L}$. Using the GH ICMA Immulite kit, an $\mathrm{n}-\mathrm{GH}$ concentration $>0.25 \mu \mathrm{g} / \mathrm{L}$ was observed in only $2 / 80$ men of our study and was practically not detected by other investigators $(11,15)(\mathrm{n}=91)$. For women, Freda et al. (7) suggested a cut-off of $0.14 \mu \mathrm{g} / \mathrm{L}(\mathrm{n}=$ 20) when using the GH IRMA DSL kit, in agreement with that observed by us in 80 adult women, but slightly lower than the value demonstrated in the present study for young and young adult women $(0.25 \mu \mathrm{g} / \mathrm{L})$ $(\mathrm{n}=40)$. When using the GH IFMA AutoDelfia kit, only $1 / 120$ women of this study and $1 / 28$ of another series (12) presented n-GH levels $>0.40 \mu \mathrm{g} / \mathrm{L}$. However, higher values have been reported by Markkanen et al. (11) for $3 / 38$ women, a difference that we could not explain based on the characteristics of the subjects

Table 2. n-GH values suggested with present results together with those reported in other studies using the same assays.

\begin{tabular}{lccc}
\hline & $\begin{array}{c}\text { IRMA (mg/L) } \\
\text { DSL kit }\end{array}$ & $\begin{array}{c}\text { IFMA (mg/L) } \\
\text { Auto Delfia kit }\end{array}$ & $\begin{array}{c}\text { ICMA (mg/L) } \\
\text { Immulite kit }\end{array}$ \\
Men & 0,14 & 0,14 & 0,25 \\
Women & 0,25 & 0,40 & 0,70 \\
\hline
\end{tabular}

or analytical variables. Using the GH ICMA Immulite kit, an $\mathrm{n}-\mathrm{GH}$ concentration $>0.70 \mu \mathrm{g} / \mathrm{L}$ was observed in only $2 / 120$ women of this study and in $2 / 147$ of the series of Arafat et al. (15), whereas Markkanen et al. (11) found values $>1 \mu \mathrm{g} / \mathrm{L}$ in $2 / 35$ women. Differences in age and BMI do not explain the higher values reported in the last study, but the fact that the preparation used for calibration of the standards did not consist of $>95 \%$ purified $22-\mathrm{kDa} \mathrm{GH}$, as used in the present study and in the series of Arafat et al. (15), may explain this difference.

The lack of an association between peak glycemia and amplitude of glycemic elevation with n-GH suggests that the administration of 75 or $100 \mathrm{~g}$ glucose yields the same results. This fact is supported by the demonstration that the variation in $\mathrm{n}-\mathrm{GH}$ and the correlation between the first and second values were the same when the second test was performed with one or the other quantity of glucose.

The definition of new normal $n-G H$ values has clinical relevance. First, it would facilitate the diagnosis of acromegaly in cases of elevated IGF- 1 and $\mathrm{n}-\mathrm{GH}<1 \mu \mathrm{g} / \mathrm{L}(5,6)$, the latter compatible with adequate suppression according to the current consensus and, therefore, excluding the disease (1). Although $<1 \mu \mathrm{g} / \mathrm{L}$, in these patients n-GH is almost always above the values found in normal individuals, characterizing the absence of suppression $(5,6)$.

In treated acromegalic patients, the laboratory finding of elevated IGF- 1 and $\mathrm{n}-\mathrm{GH}>\mathrm{l} \mu \mathrm{g} / \mathrm{L}$ characterizes "uncontrolled disease" (1); redefinition of the cut-off value does not change this interpretation. The same applies to the discordance of normal IGF- 1 and $n-G H>1 \mu \mathrm{g} / \mathrm{L}$. However, the knowledge that normal n-GH levels are lower than has been imagined (1) supports the view that levels $>1 \mu \mathrm{g} / \mathrm{L}$ are clearly altered. The data compiled from recent series $(9,10,13,15,17-21)$ show that approximately $30 \%$ of patients with elevated IGF-1 have n-GH < $1 \mu \mathrm{g} / \mathrm{L}$. About $90 \%$ of these subjects present n-GH levels above those found in normal individuals; thus, the apparent discordance results in most cases from an equivocal definition of normality since with the application of new cut-off values for $\mathrm{n}-\mathrm{GH}$ the latter and IGF-l would be altered. The same data $(9,10,13,15,17-21)$ reveal that about $25 \%$ of patients who are today regarded as being in remission (normal IGF-1 and n-GH $<1 \mu \mathrm{g} / \mathrm{L}$ (1) would present altered GH secretion after redefinition of the normality cut-off and, although presenting $\mathrm{n}-\mathrm{GH} \leq 1 \mu \mathrm{g} / \mathrm{L}$ and normal IGF-1, these patients would be at a higher risk of progressing to elevated IGF-1 (21). 
At present, no distinction could be seen between n-GH corresponding to normal suppression (used for diagnosis) and n-GH used to define remission in treated acromegalic patients $(1,3,21)$. However, follow-up studies of treated acromegalic patients may show that $\mathrm{n}-\mathrm{GH}$ values associated with clinical remission and control of morbidity and mortality do not necessarily correspond to normal suppression (12).

The present results, together with those reported in other studies using the same assays, suggest the following $\mathrm{n}-\mathrm{GH}$ reference values for the $\mathrm{GH}$ kits most used in Brazil (Table 2): for men, $0.14 \mu \mathrm{g} / \mathrm{L}$ for the $\mathrm{GH}$ IRMA DSL and GH IFMA Auto Delfia kits and 0.25 $\mu \mathrm{g} / \mathrm{L}$ for the GH ICMA Immulite kit; $0.25 \mu \mathrm{g} / \mathrm{L}$, $0.40 \mu \mathrm{g} / \mathrm{L}$ and $0.70 \mu \mathrm{g} / \mathrm{L}$, respectively, for women, with slightly higher values being observed in young women. Irrespective of age, BMI or gender, $\mathrm{n}-\mathrm{GH} \geq 1$ $\mathrm{ug} / \mathrm{L}$ almost always indicates abnormal GH secretion. In addition, the present study shows that the GH suppression test with oral glucose is reproducible and also suggests that centers using the protocol of $100 \mathrm{~g}$ glucose administration may move to $75 \mathrm{~g}$ for the sake of standardization $(1,3)$.

Dr. Pedro Weslley Rosário participa de pesquisas patrocinada pela Novartis Oncologia e Genzyme. No other potencial conflict of interest relevant to this article was reported.

\section{REFERENCES}

1. Giustina A, Barkan A, Casanueva FF, Cavagnini F, Frohman L, $\mathrm{Ho} \mathrm{K}$, et al. Criteria for cure of acromegaly: a consensus statement. J Clin Endocrinol Metab. 2000;85:526-9.

2. Trainer PJ. Editorial: acromegaly - consensus, what consensus? J Clin Endocrinol Metab. 2002;87:3534-6.

3. Melmed S. Medical progress: acromegaly. N Engl J Med. 2006;355:2558-73.

4. Sheppard MC. GH and mortality in acromegaly. J Endocrinol Invest. 2005; 28(11 Suppl International):75-7.

5. Dimaraki EV, Jaffe CA, DeMott-Friberg R, Chandler WF, Barkan AL. Acromegaly with apparently normal $\mathrm{GH}$ secretion: implications for diagnosis and follow-up. J Clin Endocrinol Metab. 2002;87:3537-42.

6. Freda PU, Reyes CM, Nuruzzaman AT, Sundeen RE, Bruce JN Basal and glucose-suppressed GH levels less than $1 \mathrm{microg} / \mathrm{L}$ in newly diagnosed acromegaly. Pituitary. 2003;6:175-80.

7. Freda PU, Landman RE, Sundeen RE, Post KD. Gender and age in the biochemical assessment of cure of acromegaly. Pituitary. 2001;4:163-71

8. Endert $\mathrm{E}$, van Rooden M, Fliers $\mathrm{E}$, Prummel MF, Wiersinga WM. Establishment of reference values for endocrine testspart V: acromegaly. Neth J Med. 2006;64:230-5.

9. Serri O, Beauregard C, Hardy J. Long-term biochemical status and disease-related morbidity in 53 postoperative patients with acromegaly. J Clin Endocrinol Metab. 2004;89:658-61.
10. Vierhapper H, Heinze G, Gessl A, Exner M, Bieglmayr C. Use of the oral glucose tolerance test to define remission in acromegaly. Metabolism. 2003;52:181-5.

11. Markkanen $H$, Pekkarinen $T$, Välimäki MJ, Alfthan $H, K a u-$ ppinen-Mäkelin R, Sane $T$, et al. Effect of sex and assay method on serum concentrations of growth hormone in patients with acromegaly and in healthy controls. Clin Chem. 2006;52:468-73.

12. Ronchi CL, Arosio M, Rizzo E, Lania AG, Beck-Peccoz P, Spada A. Adequacy of current postglucose $\mathrm{GH}$ nadir limit $1<1$ microg/l) to define long-lasting remission of acromegalic disease. Clin Endocrinol (Oxf). 2007;66:538-42.

13. Costa AC, Rossi A, Martinelli Jr CE, Machado HR, Moreira AC. Assessment of disease activity in treated acromegalic patients using a sensitive $\mathrm{GH}$ assay: should we achieve strict normal GH levels for a biochemical cure? J Clin Endocrinol Metab. 2002;87:3142-7

14. Trainer PJ, Barth J, Sturgeon C, Wieringaon G. Consensus statement on the standardisation of $\mathrm{GH}$ assays. Eur $\mathrm{J}$ Endocrinol. 2006;155:1-2.

15. Arafat AM, Möhlig M, Weickert MO, Perschel FH, Purschwitz J, et al. Growth hormone response during OGTT: the impact of assay method on the estimation of reference values in patients with acromegaly and in healthy controls and the role of gender, age, and BMI. J Clin Endocrinol Metab. 2008;93:1254-62.

16. Chapman IM, Hartman ML, Straume M, Johnson ML, Veldhuis JD, Thorner MO. Enhanced sensitivity growth hormone $(\mathrm{GH})$ chemiluminescence assay reveals lower postglucose nadir $\mathrm{GH}$ concentrations in men than women. J Clin Endocrinol Metab. 1994;78:1312-9.

17. Gullu S, Keles H, Delibasi T, Tonyukuk V, Kamel N, Erdogan G. Remission criteria for the follow-up of patients with acromegaly. Eur J Endocrinol. 2004;150:465-71.

18. Espinosa-de-Los-Monteros AL, Sosa E, Cheng S, Ochoa R, Sandoval C, Guinto G, et al. Biochemical evaluation of disease activity after pituitary surgery in acromegaly: a critical analysis of patients who spontaneously change disease status. Clin Endocrinol (Oxf). 2006;64:245-9.

19. Kauppinen-Mäkelin R, Sane T, Sintonen H, Markkanen H, Välimäki MJ, Löyttyniemi E, et al. Quality of life in treated patients with acromegaly. J Clin Endocrinol Metab. 2006;91:3891-6.

20. Colao A, Pivonello R, Cavallo LM, Gaccione M, Auriemma RS, Esposito $F$, et al. Age changes the diagnostic accuracy of mean profile and nadir growth hormone levels after oral glucose in postoperative patients with acromegaly. Clin Endocrinol (Oxf). 2006;65:250-6.

21. Freda PU, Nuruzzaman AT, Reyes CM, Sundeen RE, Post KD. Significance of "abnormal" nadir growth hormone levels after oral glucose in postoperative patients with acromegaly in remission with normal insulin-like growth factor-l levels. J Clin Endocrinol Metab. 2004;89:495-500.

\section{Correspondence to:}

Pedro Weslley Souza Rosário

Laboratório ANALYS

Av. Brasil, 738, Santa Efigênia, 30140-001 Belo Horizonte, MG, Brasil.

E-mail: pedrorosario@globo.com 